Revista do Departamento de Geografia
Universidade de São Paulo
www.revistas.usp.br/rdg

\title{
Urbanização e Alterações geomorfológicas: O Caso da Bacia Hidrográfica do Córrego Lavapés - Rio Claro (SP)
}

\author{
Urbanization and Geomorphological Changes: \\ The Case of Lavapés Stream Watershed-Rio Claro (SP)
}

\author{
Alessandra Fagundes \\ Universidade Estadual Paulista - UNESP, Rio Claro \\ fagundes_alessandra@hotmail.com \\ Cenira Maria Lupinacci \\ Universidade Estadual Paulista - UNESP, Rio Claro \\ cenira@rc.unesp.br
}

Recebido (Received): 17/08/2016 Aceito (Accepted): 21/10/2016

DOI: $10.11606 /$ rdg.v33i0.118918

Resumo: Nos últimos 60 anos, muitas cidades do Brasil praticamente dobraram seu contingente populacional. Como resultado desse processo, houve o aumento da ocupação de áreas instáveis, do ponto de vista físico, e a execução de várias intervenções antrópicas, reorganizando os processos e as formas de relevo existentes. Neste contexto, este artigo visa discutir os resultados obtidos com a análise das alterações geomorfológicas decorrentes dos processos de urbanização, na bacia hidrográfica do Córrego Lavapés, localizada no município de Rio Claro (SP). Alcançaramse os resultados apresentados através do uso da cartografia geomorfológica histórico-evolutiva, sendo. Para isso, foram elaboradas cartas geomorfológicas e de uso da terra para os anos de 1962, 1988 e 2010, e uma carta de declividade. Tais cenários foram analisados através do viés metodológico da Antropogeomorfologia, que utiliza a Teoria Geral dos Sistemas aplicada à Geografia. As principais alterações localizam-se ao longo do curso fluvial, que teve sua nascente aterrada e seu leito retificado e canalizado, sendo hoje ocupado por uma avenida. Além disso, a ocupação predominantemente urbana das vertentes alterou a topografia e o sistema de circulação das águas superficiais.

Palavras-chave: Antropogeomorfologia; Cartografia Geomorfológica; Urbanização; Uso da Terra.

\begin{abstract}
In the last 60 years, many cities in Brazil practically doubled your populations. As result of this process, there was a rise in the number of unstable areas, in the physical point of view, that were occupied and in the execution of several anthropic interventions in the natural environment, reorganizing the geographical processes and forms of existing landforms. In this context, this article aims to discuss the results obtained by the means of analysis of geomorphological changes derived from the urbanization processes, in Lavapés stream watershed, located in the city of Rio Claro (SP). The results showed here were achieved by means of the usage of historical-evolutionary geomorphological cartography. For that, there were manufactured geomorphological and land usage maps for the years of 1962, 1988 and 2010, and a declivity map. Such scenarios were analyzed by the methodological point of view of the Anthropogeomorphology, which uses General Systems Theory applied in Geography. The main changes are located over the streambed, which had your source grounded and your bed turned rectilinear and ducted, being, nowadays, covered by an avenue, besides the occupation of you sides, predominantly urbanized, factor that caused the changes in the circulation system of your surface waters.
\end{abstract}

Keywords: Antropogeomorphology; Geomorphological Cartography; Urbanization; Land Use. 


\section{INTRODUÇÃO}

A ação humana sobre os elementos da natureza tem sido historicamente construída de maneira a alterar o equilíbrio dinâmico existente entre esses elementos. A interferência antrópica se faz sentir em vários elos do sistema natural, como o clima, a vegetação, a hidrografia e o relevo (DREW, 2005).

A geomorfologia, que é a ciência que estuda as formas de relevo e os processos geomorfológicos (CHRISTOFOLETTI, 1979; MARQUES, 2001), atualmente considera o homem como um agente geomorfológico, pois esse se apropria do relevo para distintos usos, criando novos processos e gerando impactos ambientais (NIR, 1983; RODRIGUES, 1999). Entre os vários usos do relevo pelo homem, se destacam os processos e as formas geradas nos ambientes urbanos. Estes possuem dimensão espacial reduzida se comparada ao meio rural, mas processos intensos, o que resultam em paisagens extremamente artificiais.

Os estudos que buscam compreender a intensidade da atuação antrópica nos sistemas geomorfológicos são recentes no Brasil. Estes em sua maioria objetivam desenvolver metodologias para se conhecer a dimensão da atuação antrópica no relevo (JORGE, 2011; RODRIGUES, 1999, 2005, 2010).

Segundo Nir (1983, p. 8) impactos da ação antrópica sobre o relevo existem desde que o homem surgiu sobre a Terra, contudo atualmente o poder desse impacto é muito maior que no passado em função da atual "onipresença e ilimitada escala" de ocupação humana da superfície. Nesse cenário, portanto surge a necessidade da ciência geomorfológica reavaliar sua atuação.

Assim, os estudos dos processos geomorfológicos resultantes da atuação humana recebem o nome de Geomorfologia Antropogênica ou Antropogeomorfologia. Essa é definida por Rodrigues (2005) como o estudo do ambiente que resulta da presença e da intervenção antrópica no meio natural. Nir (1983) e Goudie (2006) definem a Antropogeomorfologia como o estudo no tempo e no espaço das mudanças no ambiente físico provocadas pela atuação humana. As análises sob esse viés metodológico utilizam-se dos princípios da Teoria Geral dos Sistemas e da noção de equilíbrio dinâmico.

Rodrigues (1999, 2005, 2010) tem se preocupado metodologicamente com os estudos da ação geomorfológica humana. Jorge (2011) apresenta resumidamente as propostas desenvolvidas por Rodrigues (1999) para esses estudos, entre as quais se destacam: observar as ações antrópicas como ações geomorfológicas na superfície terrestre; considerar a dinâmica e a história acumulativa das intervenções humanas, que possibilitarão o entendimento da morfodinâmica anterior às perturbações antrópicas; aplicação de diversas escalas temporais, para que as interpretações possam ser completas e coerentes; aplicar e investigar as possibilidades da cartografia geomorfológica de detalhe, já que essa pode ser uma ferramenta de grande utilidade; explorar a abordagem sistêmica; dar ênfase à abordagem de sistemas geomorfológicos, considerando que as ações antrópicas podem modificar os sistemas existentes e criar novos; levar em consideração as particularidades morfoesculturais e morfoclimáticas de um sistema, para não correr o risco da realização de análises comparativas em ambientes com características físicas diferentes.

Essa metodologia busca compreender as ações humanas como ações de natureza geomorfológica, e implica em avaliar como as ações intervêm direta e indiretamente nas formas e nos processos. Segundo Nir (1983), a organização dos espaços urbanos causa modificações hidro-geomorfológicas que devem ser compreendidas segundo estágios de desenvolvimento. Esses estágios dividem-se em três períodos: período pré-urbano, período de construção e período urbano consolidado.

Rodrigues (2005) mostra que nos estudos de geomorfologia em ambientes urbanos, deve-se identificar e representar a morfologia original (fases de pré-intervenção morfológica, ou pré-urbana) e a morfologia antropogênica, que se caracteriza pela sequência de intervenções na forma e no material original (fases de perturbação ativa e pós-ativa). A morfologia original (ou pré-intervenção) é entendida pela autora como:

(...) aquela morfologia cujos atributos como extensão, declividades, rupturas e mudanças de declives, dentre outros, não sofreram alterações significativas por intervenção antrópica direta ou indireta. Modificação significativa é aquela que já implica em dimensões métricas nos atributos mencionados (RODRIGUES, 2005, p.103).

A ação antropogênica implica em modificações significativas nos atributos naturais do relevo. Segundo Rodrigues (2005, p.106), em áreas urbanas, essa é identificada através "do padrão do arruamento, densidade de edificações, estágio de consolidação urbana, distribuição e densidade de materiais superficiais, profundidade e extensão de cortes e aterros, volume de materiais remanejados in loco ou importados". 
O levantamento dos dados é feito a partir de sequências cronológicas de fotografias áreas, entrevistas, análise da cartografia de base e levantamentos de campo.

Perante o exposto, este artigo tem o objetivo de apresentar as principais alterações geomorfológicas causadas pelos processos de urbanização na bacia hidrográfica do Córrego Lavapés, localizada no município de Rio Claro, estado de São Paulo, a partir da abordagem antropogeomorfológica. Escolheu-se essa área de pesquisa, pois a mesma apresenta suas vertentes destinadas a urbanização e seu curso d'água totalmente alterado, apresentando uma reorganização dos processos geomorfológicos da bacia. Ainda, a área registra com frequência problemas relacionados a enchentes urbanas e a subsidências que ocorrem concomitantemente na avenida que foi instalada nas margens do curso fluvial. Assim, a comunidade local sofre impactos significativos do padrão de urbanização que foi estabelecido na área.

\section{CARACTERIZAÇÃo dA ÁREA DE ESTUdo}

A bacia hidrográfica do Córrego Lavapés encontra-se na região leste da área urbana do município de Rio Claro, Estado de São Paulo, entre as coordenadas geográficas $22^{\circ} 23^{\prime} 16^{\prime \prime}$ e $22^{\circ} 24^{\prime} 53^{\prime \prime}$ latitude sul e 47³3'52" e 47³2'40" longitude oeste, ocupando uma área de $3,5 \mathrm{~km}^{2}$ e com um talvegue de aproximadamente $2,4 \mathrm{~km}$ de extensão, dos quais $1,15 \mathrm{~km}$ estão canalizados (Figura 1).

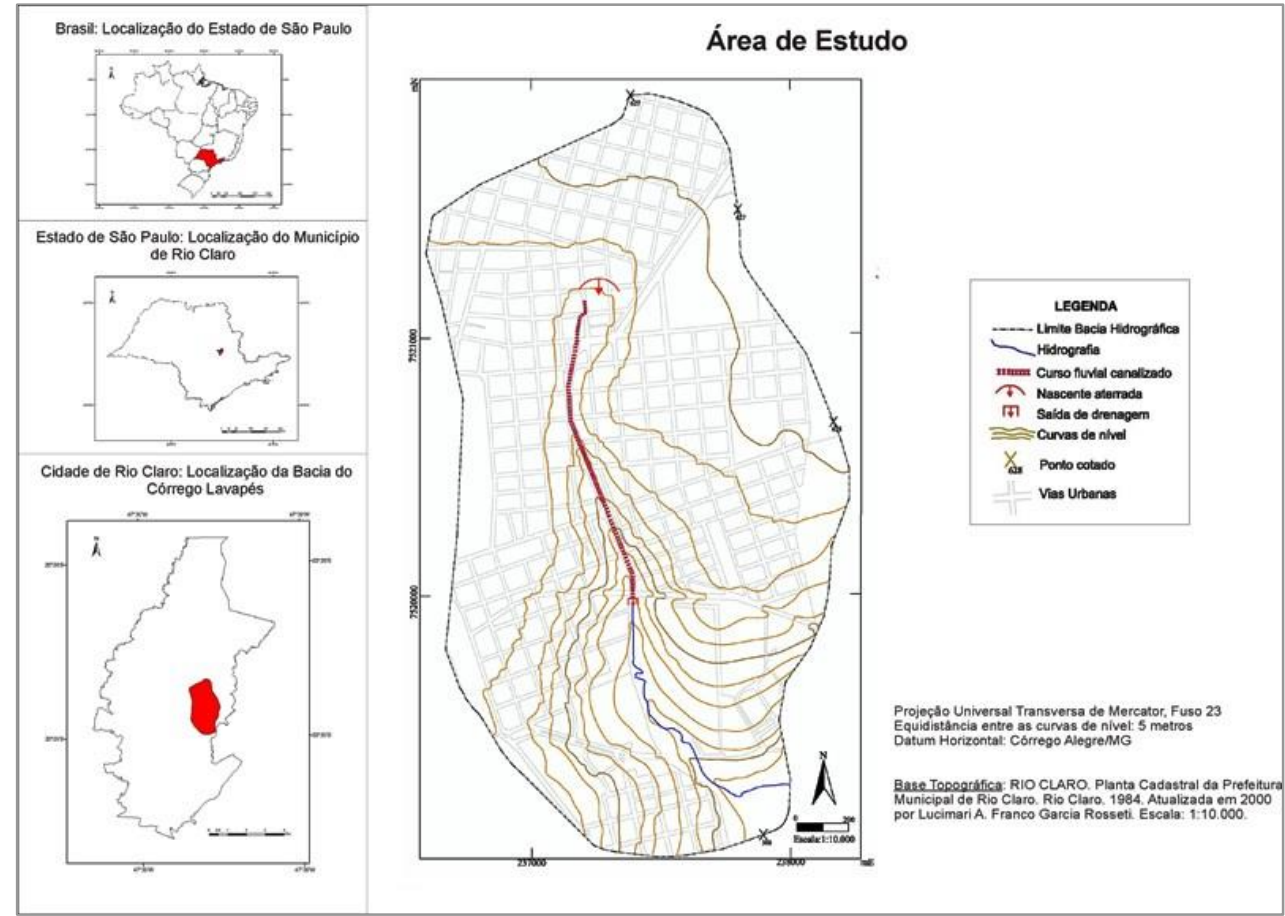

Figura 1: Localização da Bacia do Córrego Lavapés. Fonte: Planta Cadastral da Prefeitura Municipal de Rio Claro, 2000, adaptada por Rossetti (2007). Org.: Os autores.

O nome do córrego provém de um costume antigo dos moradores do município vizinho de Santa Gertrudes. Quando os mesmos dirigiam-se a Rio Claro, paravam no córrego para lavar os pés, pois o solo da área, de coloração avermelhada, impregnava nos pés e calçados (CERRI, 1999).

As principais formas do relevo da área de estudo estão vinculadas ao contexto geológico regional. A área se localiza na borda nordeste da Bacia Sedimentar do Paraná, sendo composta por rochas sedimentares da era Paleozóica (Formação Corumbataí) e da era Cenozóica (Formação Rio Claro) (COTTAS, 1983; ZAINE, 1994; HARDT, 2009).

A Formação Corumbataí é definida como a unidade superior do Grupo Passa Dois. Situa-se entre o topo da Formação Irati (pertencente ao mesmo grupo) e a base da Formação Pirambóia (Grupo São Bento). Sua formação provavelmente relaciona-se a depósitos marinhos de planícies de maré, sendo admitidas condições mais continentais para o topo. Sua litologia é constituída por argilitos, siltitos, lamitos e folhelhos marromavermelhados e arroxeados, às vezes esverdeados, com intercalações de lentes carbonáticos e coquinhas. 
(IPT, 1981; ZAINE, 1994). Os solos resultantes da alteração da Formação Corumbataí possuem caráter argiloso com intercalações arenosas ou siltosas (argissolos). Sua espessura é muito variada, podendo chegar a 10 metros (IPT, 1981).

Segundo Zaine (1994, p.76), "a Formação Rio Claro constitui-se no registro mais significativo, e provavelmente, mais antigo do Cenozóico". Sua litologia apresenta, na parte inferior, arenitos inconsolidados de coloração amarela que apresentam intercalações de leitos de argilitos isolados com espessuras variáveis, e na parte superior, material areno-argiloso, sem estruturas de cores, com acentuado grau de laterização. A espessura máxima registrada é da ordem de $30 \mathrm{~m}$ e a unidade capeia os principais interflúvios, formando extensos tabuleiros. (COTTAS, 1983; ZAINE, 1994). Os solos resultantes da alteração da Formação Rio Claro apresentam coloração vermelho-amarelada (latossolos vermelho-amarelos), arenosos e espessos (profundidade máxima de 10 a $12 \mathrm{~m}$ ) e ácidos, com soma e saturação em bases muito baixas, e com alumínio trocável ao longo do perfil (COTTAS, 1983; ZAINE, 1994).

Seus terrenos caracterizam-se por possuírem topografia suave, com interflúvios subtabulares, normalmente cobertos por sedimentos arenosos, extensos e aplainados, sem linha de cumeada bem definida; possuem vertentes com perfis retilíneos a convexos no alto, com altitudes que oscilam entre 550 e 650 metros, e vertentes com perfil côncavo no sopé. Possuem baixa densidade de drenagem, e é comum a presença de lagoas ligadas às cabeceiras ou isoladas nos topos planos. (COTTAS, 1983; ZAINE, 1994; HARDT, 2009).

O clima da área, segundo a classificação de Köppen é do tipo Cwa, ou seja, seco no inverno (w), com temperaturas inferiores a $18^{\circ}$, e chuvoso no verão (a), com temperaturas superiores a $22^{\circ}$. O regime de chuvas é tropical, quanto à distribuição anual (COTTAS, 1983; ZAINE, 1994).

As condições físicas relatadas criam certas dificuldades ao gerenciamento do espaço urbano. Assim, ao estudar o sítio urbano de Rio Claro na década de 1980, Penteado (1981, p. 31) já afirmava que a "erosão acelerada ou erosão antrópica é o aspecto mais característico da paisagem". O Instituto de Pesquisas Tecnológicas - IPT (1989, citado por ZAINE, 2000) identificou e cadastrou erosões na área urbana que o levaram a considerar o município como setor crítico a processos erosivos. Obras de retificação e canalização de drenagens para dar lugar a novos espaços de ocupação foram realizadas em diversos canais fluviais que cortam sua área urbana. A obra de canalização mais expressiva do município é a que se localiza no trecho urbano da bacia hidrográfica do Córrego da Servidão. Nessa área, caracterizada por ocupação urbana antiga, se encontra a principal via do município, a Avenida Visconde de Rio Claro (MORUZZI et al., 2009). Quando há a ocorrência de temporais, os moradores encontram dificuldades em transitar pela mesma. Situação semelhante esboça-se na bacia hidrográfica do Córrego Lavapés.

\section{MATERIAIS E TÉCNICAS}

A pesquisa foi desenvolvida utilizando-se de princípios da Teoria Geral dos Sistemas aplicados à Geografia, sendo que os mesmos integram a abordagem da Antropogeomorfologia (NIR, 1983; RODRIGUES, 2005). Utilizaram-se os critérios abarcados pelos sistemas controlados. Segundo Christofoletti (1979, p.19), esses sistemas "apresentam a ação do homem sobre os sistemas de processosresposta. A complexidade é aumentada pela intervenção humana". Quando se examinam as estruturas desses sistemas, verifica-se a existência de variáveis chaves, nas quais o homem pode intervir para realizar modificações na distribuição da matéria e da energia e, consequentemente, influenciar nas formas que estão relacionadas.

Esse aspecto do sistema foi avaliado através de uma análise correlativa entre os dados obtidos com as cartas de uso da terra e geomorfológicas dos cenários de 1962, 1988 e 2010 da bacia do Córrego Lavapés. Para a construção do cenário de 1962, utilizaram-se fotografias aéreas do Instituto Agronômico de Campinas, na escala de 1:25.000. Para o cenário de 1988, utilizaram-se fotografias aéreas da empresa Terra Foto S.A., na escala de 1:40.000. Para o cenário de 2010, utilizaram-se fotografias aéreas da empresa SRR Tecnologia, Engenharia e Aerofotolevantamentos, na escala de 1:1.000.

As cartas geomorfológicas foram construídas conforme as técnicas propostas por Tricart (1965) e Verstappen e Zuidam (1975). As duas técnicas têm como base a fotointerpretação de pares estereoscópicos de fotografias aéreas do terreno, possibilitando assim, o levantamento de dados para a constituição de mapas geomorfológicos de detalhe. Porém, as mesmas foram adaptadas para o cenário geomorfológico de 2010, no qual se utilizou imagens que não permitiam fotointerpretação. Assim, as informações foram complementadas 
através de trabalhos de campo. Houve adaptação no que diz respeito ao uso das simbologias propostas por Tricart (1965), objetivando facilitar a leitura do documento final.

Para a representação da morfologia antropogênica, adaptou-se a proposta apresentada por Rodrigues (2005) para os símbolos de nascente aterrada, ruptura topográfica antrópica e saída de drenagem, e a proposta apresentada por Silveira (2009) para o símbolo de drenagem canalizada.

As cartas de uso da terra foram elaboradas através da interpretação das fotografias aéreas dos anos de 1962, 1988 e 2010, baseando-se na proposta de Ceron e Diniz (1966). As classes de uso da terra foram estabelecidas conforme parâmetros estabelecidos pelo Instituto Brasileiro de Geografia e Estatística (IBGE, 2006), com adaptações à realidade estudada. A construção e edição dos produtos cartográficos foram realizadas utilizando-se o programa AutoCAD Map 2004.

\section{RESULTADOS E DISCUSSÕES}

Através da interpretação das informações obtidas nos mapeamentos geomorfológicos, pode-se considerar que durante o período histórico estudado, ocorreram diversas alterações nas formas de relevo da bacia. As principais alterações são a seguir apresentadas de acordo com o processo geomorfológico dominante que as criaram:

Formas de origem denudativa: notou-se uma diminuição nos números de sulcos erosivos e uma reorganização das rupturas topográficas. Muitas dessas rupturas encontram-se modificadas. Essas modificações foram causadas em sua maioria pela mudança do uso da terra, que foi destinado à urbanização. Os processos de terraplenagem para construções de edificações e ruas modificam o modelado do relevo urbano, alterando ou eliminando formas existentes. As formas antropizadas passam a desencadear novos processos, gerando novas formas sobre as existentes.

Ação das aguas correntes e formas de origem fluvial: quanto às feições hidrográficas, notaram-se transformações na morfologia do leito fluvial do córrego, que teve sua nascente aterrada, seu talvegue retilinizado e canalizado e seu leito maior transformado em uma avenida; os canais pluviais não acompanham a topografia, mas o traçado das ruas, desde o período pré-urbanização. Quanto às feições de acumulação, notou-se que em 1962 a área de acumulação de planície e terraço fluvial (APTF) encontravase visível, sem ocupação antrópica em toda sua extensão; em 1988, essa foi substituída pela avenida na alta bacia e em parte da média bacia; em 2010, a área de acumulação era registrada somente na baixa bacia. Registrou-se ainda a presença de um leque aluvial na foz da drenagem principal nos três cenários estudados. Sua área sofreu variação no decorrer dos anos. Atualmente, esse se encontra utilizado por uma pequena propriedade agrícola.

Modelado antrópico: em 1962, a única forma antrópica identificada refere-se a um corte topográfico de uma via urbana, na média bacia. Em 1988, além do corte topográfico, identificaram-se alterações antrópicas no leito fluvial, como o aterramento da nascente e a canalização de parte do curso do córrego. Em 2010, foram destacadas as mesmas alterações do cenário de 1988. Porém, houve um corte topográfico em um lote da média bacia.

As alterações geomorfológicas narradas foram desencadeadas em um relevo que possui $52 \%$ de sua área com declives inferiores ou iguais a 2\% (Figura 2). As áreas dessa classe de declividade são suscetíveis a inundações, devendo sua ocupação ser realizada com restrições. A segunda maior classe de declividade ocupa $27,7 \%$ de área com declives que variam de 5 a $15 \%$. Nessas áreas, as possibilidades de urbanização sem restrições atingem seu nível máximo. A terceira maior classe de declividade ocupa $18,3 \%$ de área com declives que variam de 2 a $5 \%$. Nestas, a urbanização pode ser realizada sem restrições quanto a possibilidade de inundações. As demais classes (15 a 30\% e > 30\%) possuem áreas pequenas na bacia hidrográfica; juntas, representam $2 \%$ do total. Essas classes possuem restrições regulamentadas pela legislação para o seu uso e ocupação em áreas urbanas. Portanto, é possível considerar que o relevo da bacia encontra-se em uma área relativamente plana, principalmente nas proximidades da drenagem e nos setores de topo, o que fez com que determinados processos fossem intensificados após as intervenções antrópicas, como as enchentes no entorno do córrego e a acumulação de água pluvial nas vias de circulação estabelecidas nos setores de topo. 
Esse relevo com baixas declividades propiciou a intensificação do seu uso e ocupação. A Figura 3 apresenta a distribuição das classes de uso da terra nos três cenários. A interpretação desses dados em conjunto com as análises espaciais permite considerar que o uso da terra na bacia hidrográfica foi amplamente destinado à expansão urbana.

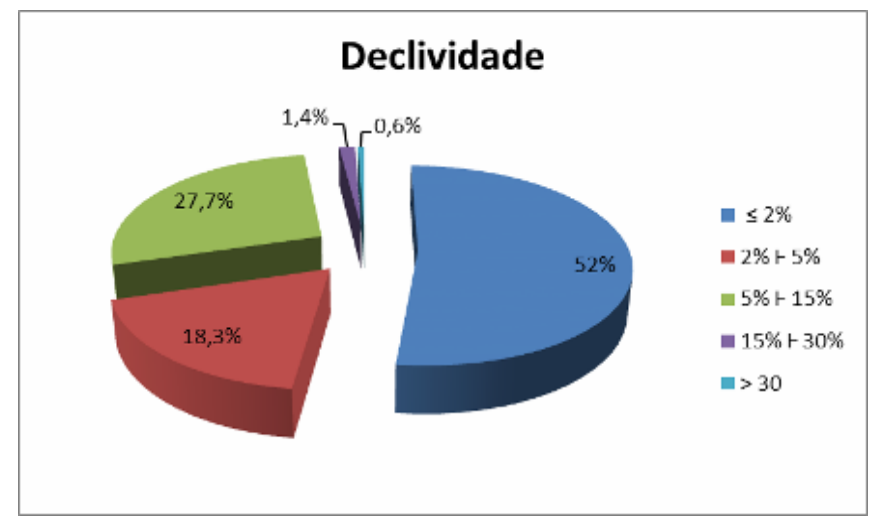

Figura 2: Porcentagens das classes de declividade da área de estudo. Fonte: Mapa de Declividade. Org: Os autores.

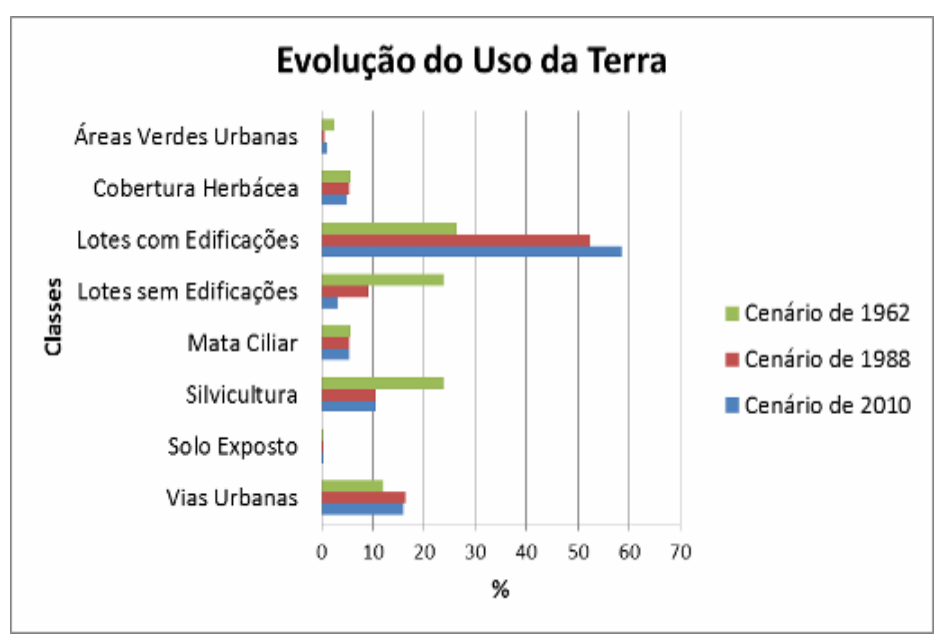

Figura 3: Evolução do uso da terra na bacia do Córrego Lavapés. Fonte: Mapas de uso da terra de 1962, 1988 e 2012. Org: Os autores.

Analisando os dados, é possível constatar que em 1962 a área da bacia possuía três usos bem definidos: lotes com edificação, lotes sem edificação e silvicultura. Esses três usos são característicos de áreas com forte atuação antrópica. Os lotes eram, em sua maioria, destinados a construção civil. A silvicultura, neste caso, tinha como principal objetivo o de fornecer matéria prima para a construção e manutenção dos trilhos das Ferrovias Paulista S.A. (Antiga FEPASA) (Figura 4).

Em 1988, a área com lotes com edificações passa a constituir mais de 50\% da área ocupada pela bacia. A silvicultura e os lotes sem edificação sofreram reduções em suas áreas totais. Outro uso que sofreu redução foi o de áreas urbanas verdes. Esse, que possuía 2,57\% em 1962, ocupa 0,57\% de área em 1988.

Em 2010, a área de lotes com edificação ocupa quase 60\% da área total da bacia. Os lotes sem edificações tiveram outra redução no período. As áreas verdes urbanas passaram a constituir 1,14\% do uso total da terra. A Figura 5 apresenta a evolução espacial do uso da terra destinado à urbanização.

Considera-se que as principais mudanças morfológicas na bacia estão relacionadas à apropriação e transformação de seu sistema natural para um sistema controlado, visando favorecer a organização espacial urbana. Sabe-se que a construção de ambientes urbanos modifica os fluxos de matéria e energia. Para facilitar a exposição desses resultados, buscou-se analisar a área estudada por meio da compartimentação setorial da bacia hidrográfica, objetivando destacar os trechos de maior alteração geomorfológica causados pelas mudanças no uso da terra. A divisão setorial teve como base os bairros existentes, de maneira a aproximar a divisão da bacia hidrográfica em alta (1), média (2) e baixa (3) bacia (Figura 6). 


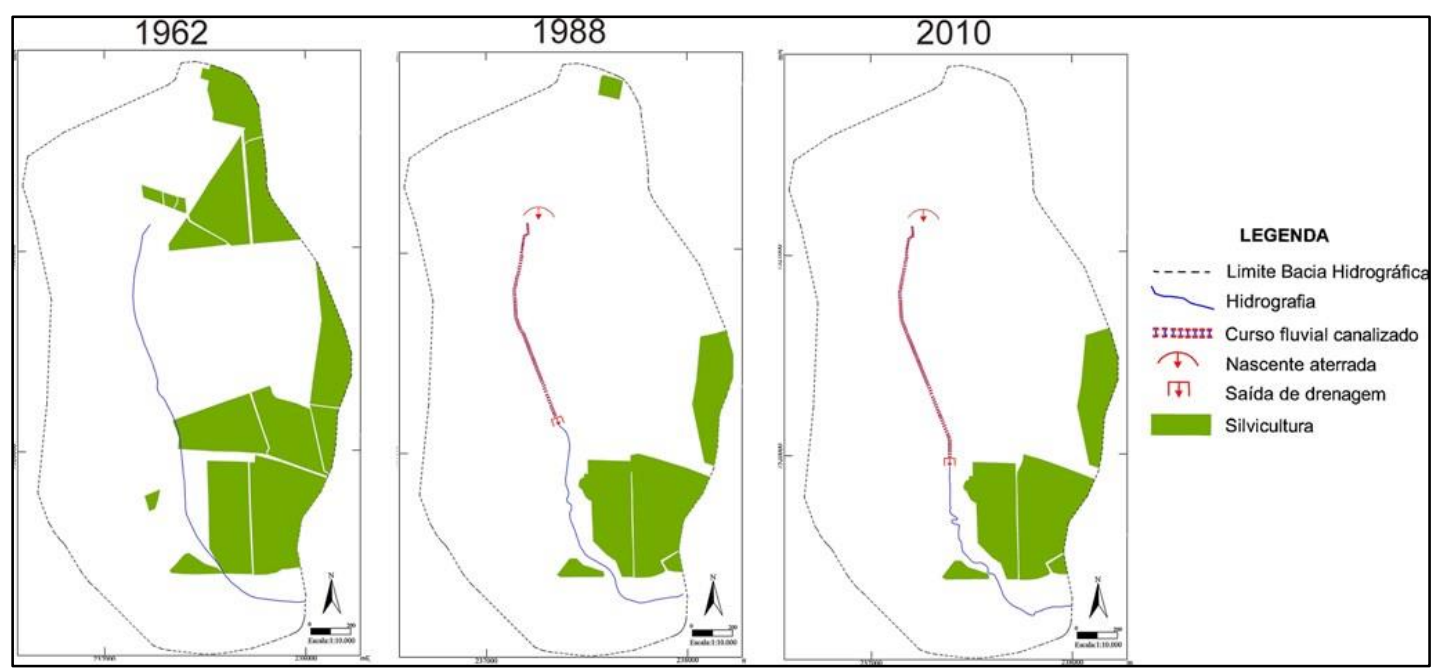

Figura 4: Evolução espacial da área de silvicultura. Fonte: Mapas de uso da terra de 1962, 1988 e 2010. Org: Os autores.

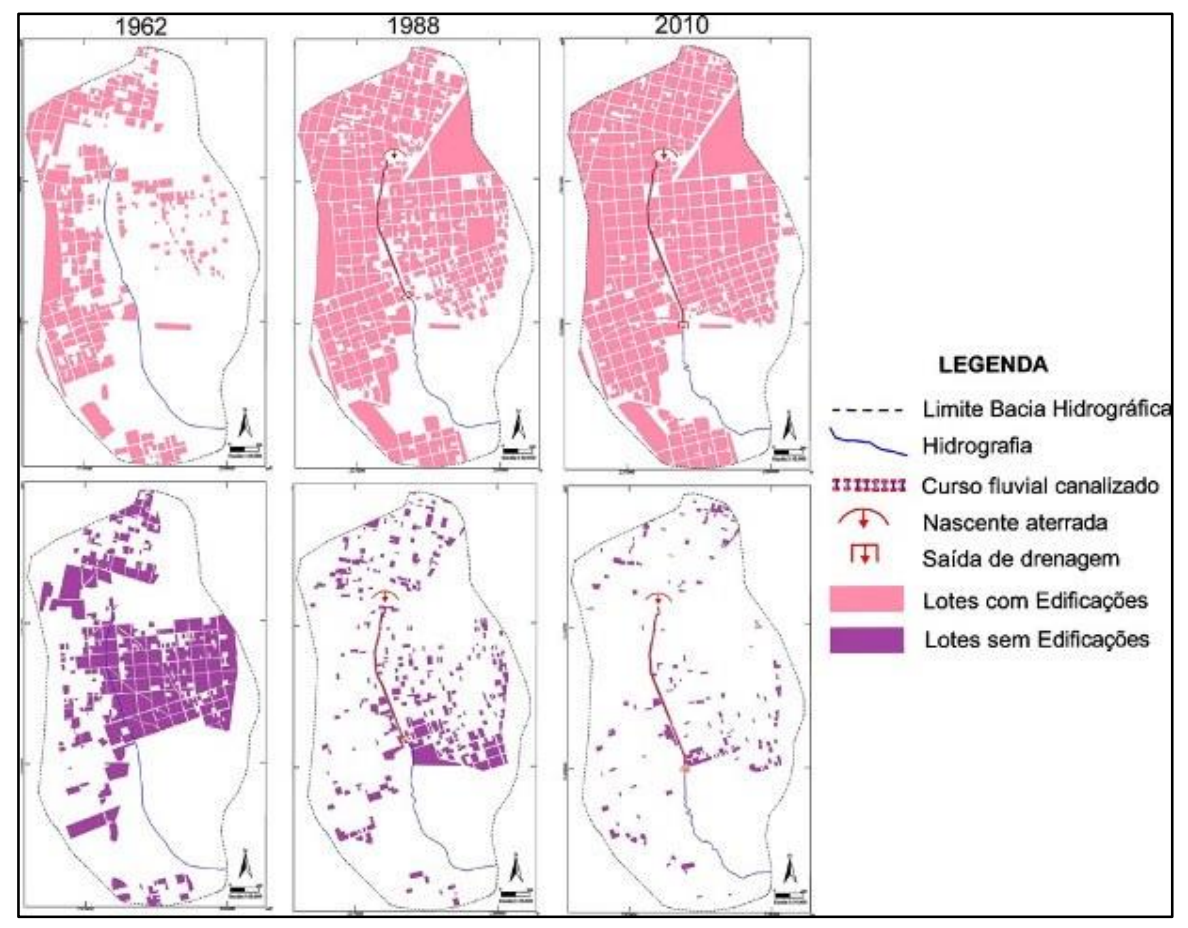

Figura 5: Evolução espacial dos lotes edificados (em rosa) e não edificados (em roxo - com arruamentos, mas sem área construída). Fonte: Mapas de uso da terra de 1962, 1988 e 2010. Org: Os autores.

$\mathrm{Na}$ alta bacia, pode-se verificar a partir do mapeamento geomorfológico para o cenário de 1962, que os canais pluviais vinculados à topografia estavam direcionados à nascente do córrego, que era vinculada a uma lagoa. Essa lagoa provavelmente se formou por causa da evolução morfológica da Formação Rio Claro, conforme as informações obtidas de Zaine (1994). Porém, verificou-se a partir das imagens aéreas, que a área próxima a essa nascente, neste mesmo cenário, já se encontrava ocupada por edificações e por traçados de ruas. Segundo Rossetti (2007), em 1962, o curso do córrego encontrava-se retificado e preparado para canalização e incorporação na malha viária (Figura 7).

O uso da terra da alta bacia apresentava em 1962, o que Nir (1983) chama de estágio de construção. Os bairros Vila Alemã e Vila Nova foram consolidados nos terrenos da bacia que possuem declividade menor ou igual a $2 \%$. Dos lotes existentes no período, metade encontrava-se construído e metade sem construções (Figura 5). A área que se localiza a nascente encontrava-se ocupada por cobertura herbácea. Próximo a sua cabeceira, encontravam-se algumas áreas com silvicultura e lotes sem edificação (Figura 8). 


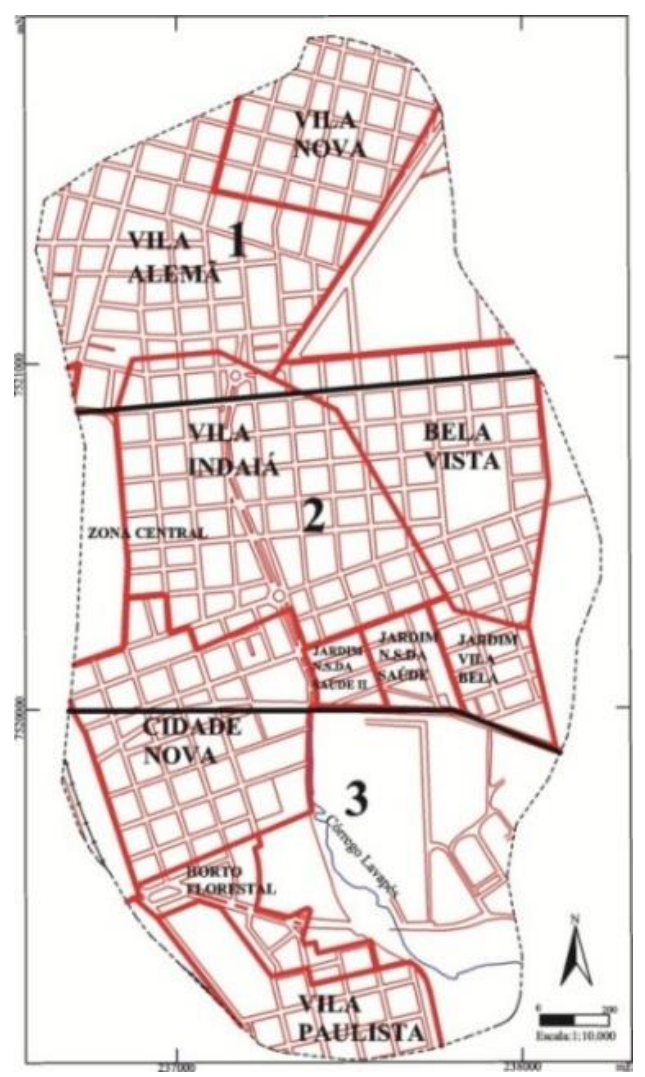

Figura 6: Compartimentação Analítica. Fonte: Planta Cadastral da Prefeitura Municipal de Rio Claro, 2000, adaptada por Rossetti (2007). Org: Os autores.

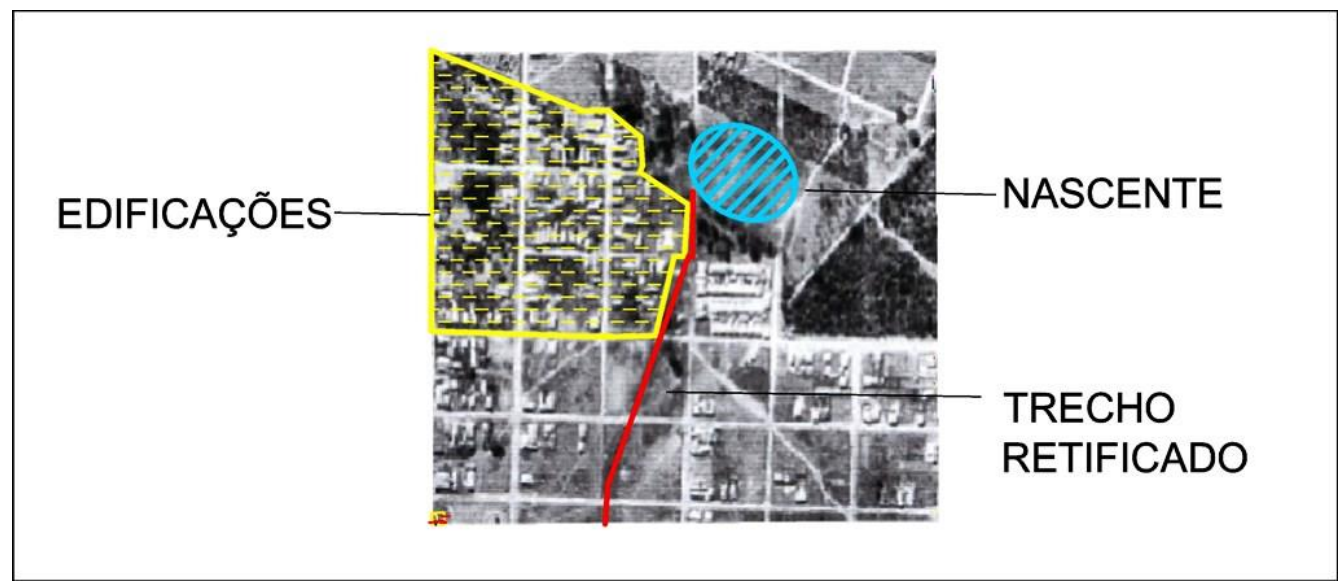

Figura 7: Setor de nascente do Córrego Lavapés em 1962. Fonte: Instituto Agronômico de Campinas (1962).

Org: Os autores.

Os Bairros Vila Nova e Vila Alemã, que se encontravam, segundo o conceito de Nir (1983), no estágio de construção em 1962, apresentaram, em 1988, o que o autor chama de urbanização consolidada. As classes lotes sem edificações e silvicultura tiveram reduções em relação ao cenário de 1962. Essas foram incorporadas a urbanização.

A área da nascente do córrego já se encontrava organizada em quadras. As áreas que em 1962 possuíam cobertura herbácea, em 1988 apresentavam-se com lotes edificados. Apenas a área da nascente e duas áreas próximas se encontravam com cobertura herbácea (Figura 8).

Em 2010, a área da nascente encontrava-se com o mesmo padrão organizacional do cenário de 1988. Porém, foram observadas algumas alterações no uso da terra. Notou-se um adensamento das áreas edificadas, em relação a 1988 (Figura 8).

As alterações geomorfológicas mais expressivas da alta bacia foram observadas em seu setor de nascente. A Figura 9 apresenta três alterações que foram identificadas entre os anos de 1962 e 2010. As mesmas estão identificadas pelos números 1,2 e 3 . 


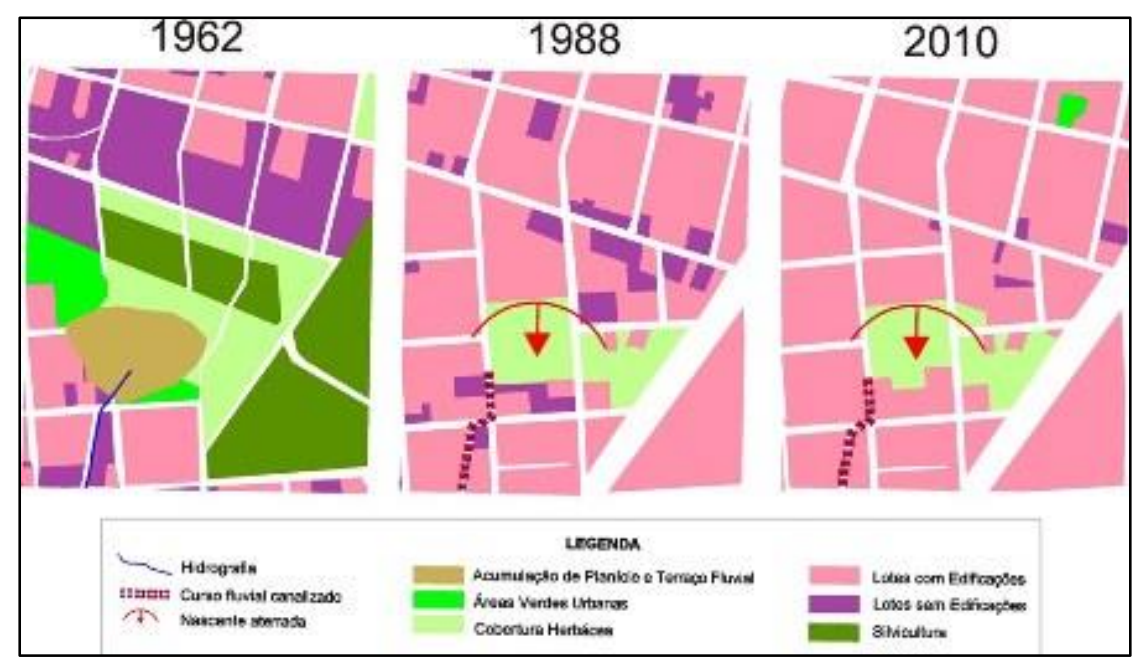

Figura 8: Evolução do uso da terra na área de nascente. Fonte: Mapas de Uso da Terra de 1962, 1988 e 2010. Org.: Os autores.

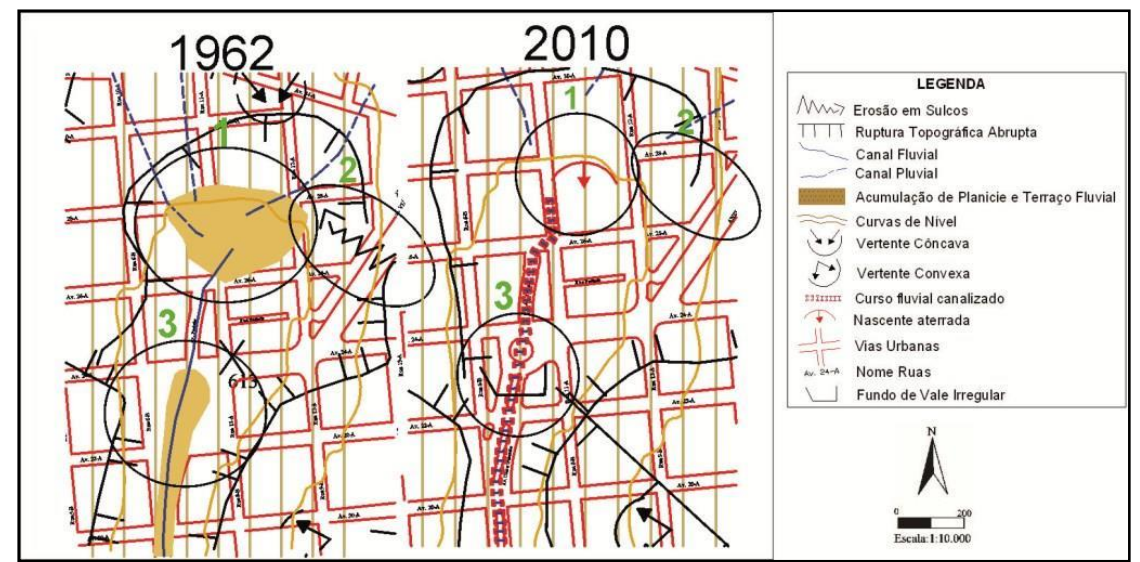

Figura 9: Modificações identificadas no setor de nascente da bacia hidrográfica do Córrego Lavapés. Fonte: Cartas geomorfológicas de 1962 e 2010. Org: Os autores.

Nota-se que no cenário de 1962, a área próxima a nascente do córrego encontrava-se em processo inicial de urbanização. Esse foi identificado como sendo um terreno alagadiço, mas os dados geológicos informam que o mesmo era no passado uma lagoa de cabeceira. Em 2010, toda a área encontra-se urbanizada, com lotes e traçados de ruas definidos. A nascente se encontra aterrada em um lote. Atualmente o terreno é utilizado como estacionamento de uma instituição religiosa (Figuras 9 e 10).

Em 1962 constatou-se a presença de um sulco erosivo próximo a área da nascente, indicando concentração do escoamento superficial naquele local. Em 2010, não há a identificação desse sulco, que provavelmente foi eliminado a partir dos processos de terraplenagem para construção de edificações (Figura 9). Hoje, o escoamento superficial da área é controlado por sistemas de galerias pluviais, que direcionam os fluxos para o córrego canalizado.

A área identificada na Figura 9 pelo número 3 apresenta, em 2010, uma rotatória e uma praça, dividida pela via. Nesta, encontra-se o atual curso do córrego. Os trabalhos de campo para reambulação dos dados permitiram constatar a existência de um fundo de vale dissimétrico. Sua dissimetria é observável no cenário de 1962 através da configuração da área de acumulação de planície e terraço fluvial (APTF). A margem direita do córrego apresentava uma dinâmica erosiva e a margem esquerda apresentava uma dinâmica deposicional. Essa informação pode indicar que naquele local as características litológicas interviam na dinâmica do curso do córrego.

$\mathrm{Na}$ média bacia, foi possível identificar um corte topográfico antrópico, em um terreno localizado na Avenida Ulisses Guimarães com a Avenida 8-A. Neste terreno registra-se a principal evidência da alteração antrópica do leito fluvial do Córrego Lavapés (Figura 11). 


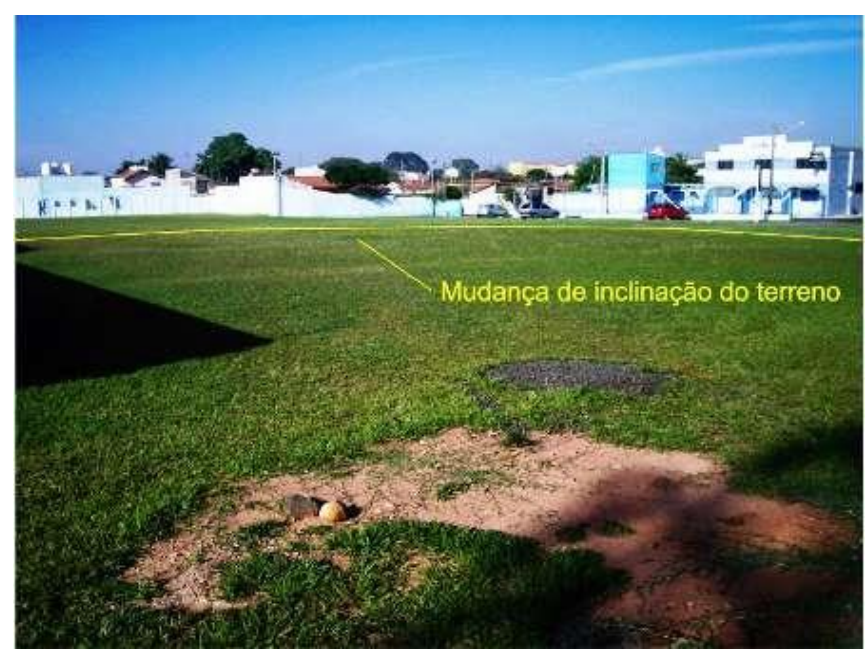

Figura 10: Terreno onde se localizava a nascente do Córrego Lavapés e que hoje é utilizado como estacionamento de uma instituição religiosa. Notar mudança suave na forma do terreno devido à baixa declividade (em amarelo). Foto: Os autores.

A constatação dessa modificação surgiu no primeiro trabalho de campo para reambulação inicial dos dados de 2010. Neste, notou-se a presença de uma vegetação típica de áreas alagadas em um terreno localizado na margem esquerda da Avenida Ulisses Guimarães com a Avenida 8-A. Após o campo, realizouse a verificação desse terreno nas imagens aéreas de 1962. Constatou-se que o mesmo era parte do leito maior do córrego antes da sua canalização (Figura 12 - 1962). Atualmente, o trecho do córrego que passava por esse terreno encontra-se canalizado, debaixo da avenida, o que permitiu considerar que seu traçado foi alterado.

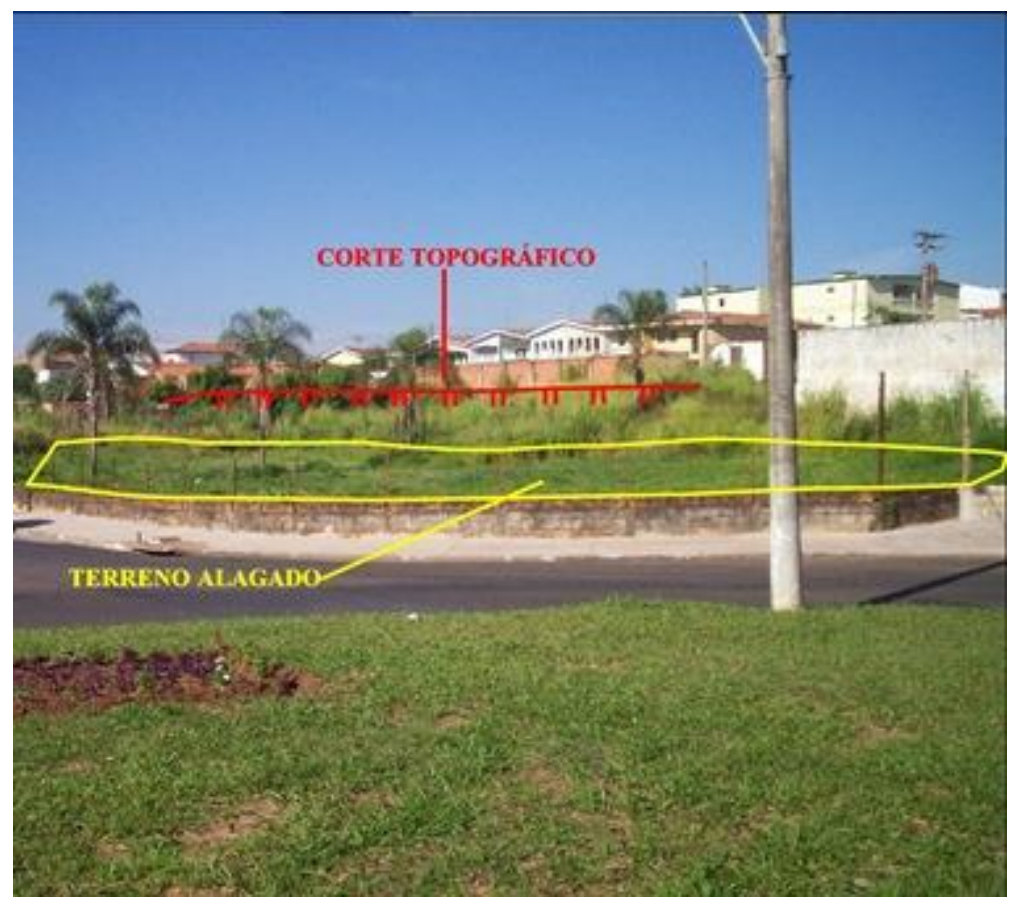

Figura 11: Corte topográfico antrópico e terreno alagado no médio curso. Foto: Os autores. Org: Os autores.

No segundo trabalho de campo, realizou-se uma verificação mais apurada no terreno. Ao se caminhar pelo mesmo, constatou-se a presença de água no solo, a existência de um corte topográfico antrópico e de alicerces. Esses alicerces indicam que no local havia alguma edificação, que atualmente encontra-se destruída. Nas imagens aéreas de 1988 é possível notar a existência de uma edificação que ocupava quase todo o terreno. Em 2010, esse terreno encontra-se totalmente ocupado pela vegetação. Dessa forma, mapeouse a alteração das formas de relevo da área entre os anos de 1988 e 2010, conforme apresentado na Figura 12. 


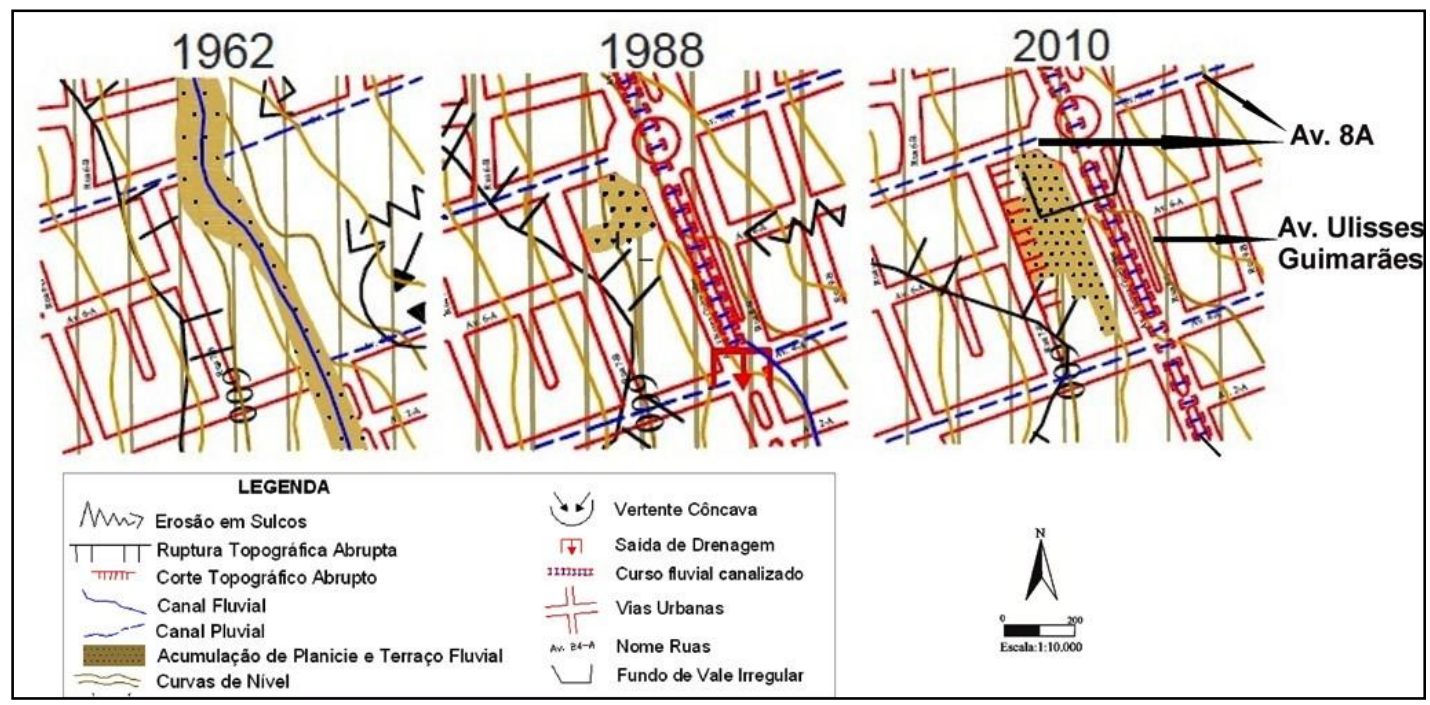

Figura 12: Alterações geomorfológicas observadas no médio curso da bacia hidrográfica do Córrego Lavapés. Fonte: Cartas Geomorfológicas - 1962, 1988 e 2010. Org.: Os autores.

Na baixa bacia localiza-se a saída de drenagem do Córrego Lavapés da estrutura de canalização, identificada no cenário de 2010 (Figura 13). Nesta, é possível observar que a água possui uma tonalidade escura, indicando o recebimento de fluxos provenientes das ruas. É possível observar também a quantidade de resíduos sólidos e sedimentos acumulados próximos a essa saída. Esses resíduos caracterizam-se, conforme propõe a geomorfologia urbana, como depósitos tecnogênicos, que são constituídos por material gerado pelas atividades antrópicas nas vertentes, gerando depósitos construídos ou induzidos. A existência desses depósitos indica forte intervenção antrópica no uso e ocupação da terra.

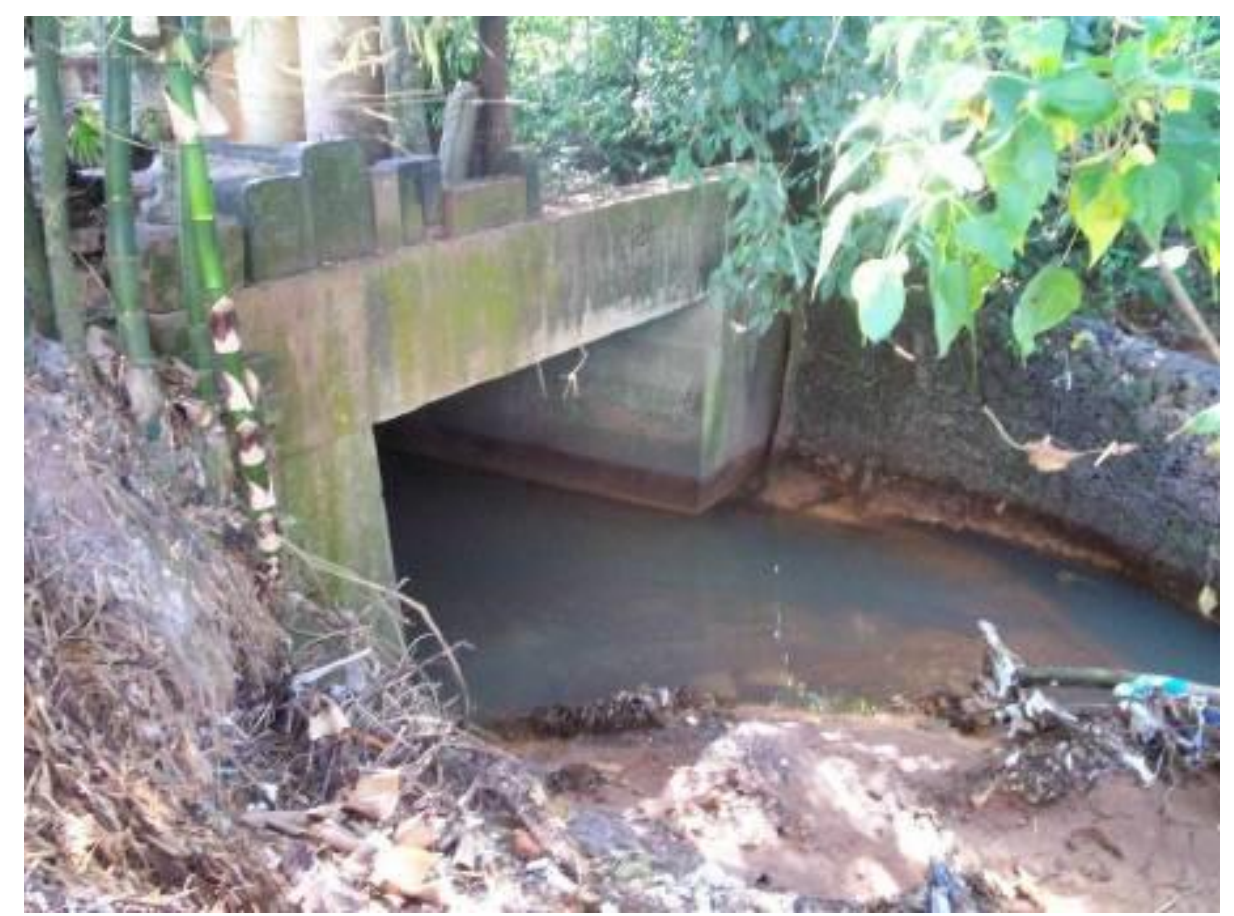

Figura 13: Local onde ocorre o término da canalização do Córrego Lavapés. Destaque para a tonalidade da água e quantidade de sedimentos e resíduos sólidos acumulados (canto inferior direito da foto). Foto: Os autores. 


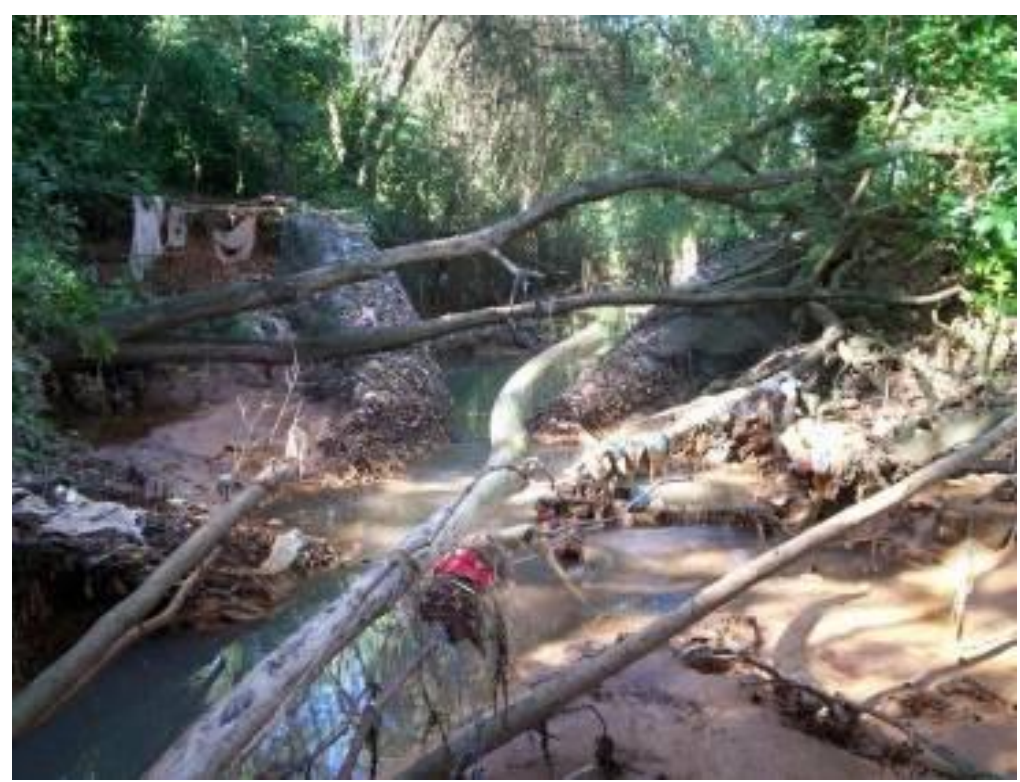

Figura 14: Trecho localizado após a saída de drenagem. Foto: Os autores.

A Figura 14 apresenta a situação do trecho localizado após o local da saída de drenagem. Os gabiões neste trecho não suportaram o peso do material acumulado nas vertentes e cederam. Segundo informações de pessoas que trabalham próximo ao local, esse fato ocorreu após fortes chuvas. Nesta Figura, destaca-se que a composição do material acumulado é de sedimentos finos, provavelmente provenientes do solo de alteração da Formação Rio Claro.

A Figura 15 apresenta o leito do córrego retificado após a saída da drenagem do setor canalizado. Este se encontra com várias rochas em seu leito maior. Essas objetivam criar obstáculos, para que as águas que chegam do trecho canalizado possam ter seu nível de energia reduzido, evitando-se assim, a erosão das margens. A Figura 16 apresenta um trecho do córrego próximo a ponte que faz a ligação da Floresta Estadual Edmundo Navarro de Andrade (FEENA) com a cidade. Nota-se nesse trecho (canto inferior direito) que parte do talvegue encontra-se impermeabilizado. Ao se observar o canto superior direito da figura, notase que há uma dinâmica deposicional do córrego. Porém, há uma dinâmica erosiva, com aumento da energia, quando este ultrapassa a impermeabilização.

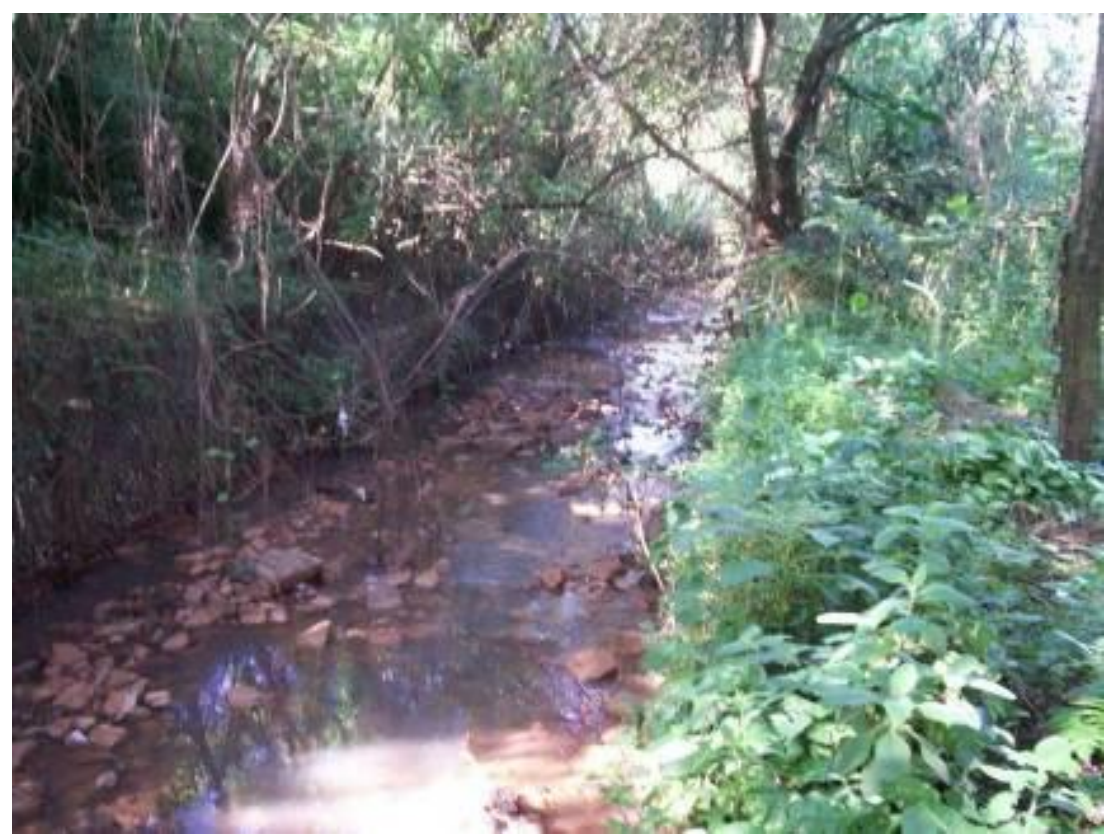

Figura 15: Fundo de vale do Córrego Lavapés no trecho retificado da baixa bacia. Notar presença de rochas. Foto: Os autores. 


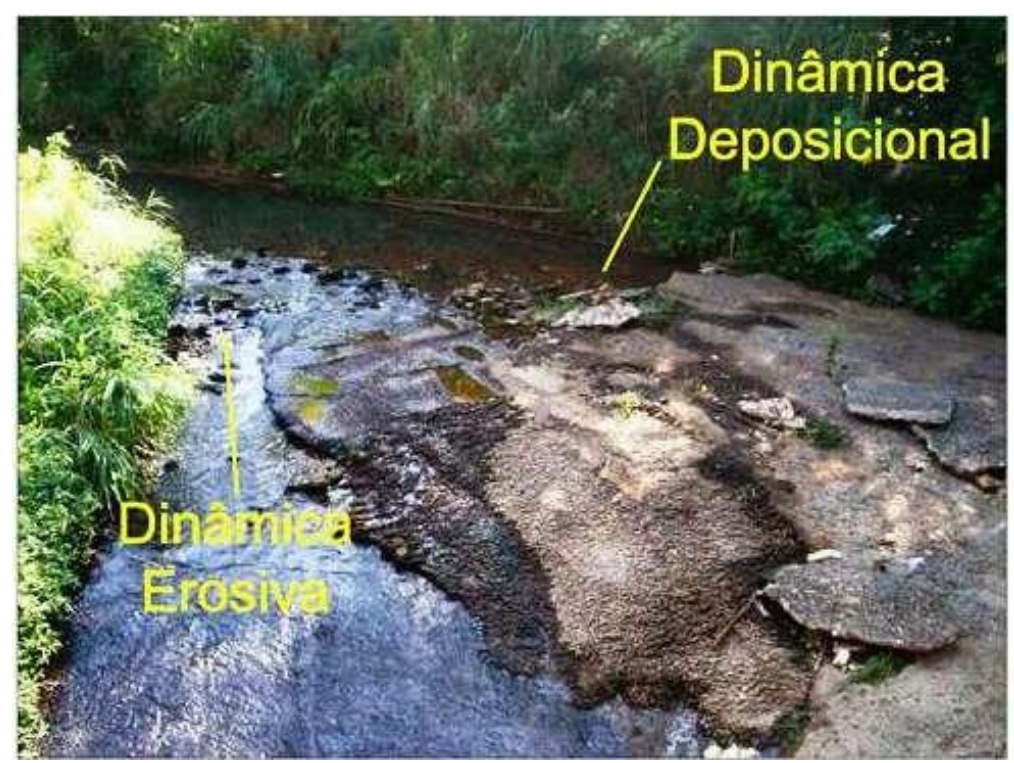

Figura 16: Trecho do córrego próximo à ponte que liga a FEENA a cidade. Nota-se que em uma das margens, o rio possui uma dinâmica deposicional, e na outra, uma dinâmica erosiva com alta energia. Foto: Os autores.

Ainda, em trabalho de campo, analisou-se o terreno no qual se registrou a presença do leque aluvial e a dinâmica do Córrego Lavapés em sua foz. Por suas características geomorfológicas, que implicam em alta suscetibilidade erosiva e pouca capacidade de suporte devido ao material pouco consolidado, se considera o leque aluvial como uma área restrita ao uso. Porém, não foi o que se notou no local. O mesmo é ocupado por uma pequena propriedade rural, onde há criação de gado e equinos. Os animais são soltos em toda a extensão do leque, que apresenta vários pontos de proximidade com o lençol freático. O pisoteio desses animais no terreno e nas margens do córrego podem causar interferências em sua dinâmica erosiva.

No leque aluvial, foi possível registrar a dinâmica do córrego antes de se encontrar com o Ribeirão Claro. O mesmo possui uma fraca energia, o que gera muitas áreas de deposição de sedimentos a montante da foz. A Figura 17 destaca seis pontos que demonstram os processos que ocorrem no local.

Na Figura 17A, notam-se os sedimentos depositados na margem direita e a proximidade com a mata ciliar. A margem esquerda apresenta uma dinâmica erosiva. É possível notar que o curso d'água encontra-se com baixa energia em seu fluxo. Na Figura 17B, é possível ver por outro ângulo a margem erosiva e outro ponto de deposição de sedimentos. A Figura 17C apresenta uma ilha de sedimentos localizada no meio do córrego. Muitos desses sedimentos são provenientes da erosão das margens, acrescidos de materiais tecnogênicos.

A Figura 17D apresenta uma pequena diferença altimétrica entre o leito do córrego e o leque aluvial. Essa diferença pode indicar que durante as cheias do córrego, o mesmo tende a extravasar suas águas para a área do leque, alagando-o. A Figura 17E apresenta o talvegue do córrego antes de desaguar no Ribeirão Claro. Note que o córrego não tem forças para aprofundar seu leito, depositando seus sedimentos em toda a extensão do talvegue. Na Figura 17F é possível verificar o encontro do Córrego Lavapés com o Ribeirão Claro.

A dinâmica do Córrego Lavapés nos trechos destacados pode estar relacionada às intervenções antrópicas realizadas durante quase 50 anos na bacia hidrográfica. A ocupação de suas vertentes e de seu vale na alta e média bacia fez com que o mesmo modificasse os seus processos. A existência do leque aluvial indica que o córrego possuía uma capacidade erosiva e de transporte de sedimentos mais alta do que a atual. Hoje, o mesmo encontra-se quase assoreado, sem forças para escavar seu leito, depositando os sedimentos em diversos locais. Seu encontro com o Ribeirão Claro ocorre tranquilamente. Só é possível distingui-los através da diferença de cor das águas (Figura 17F). 


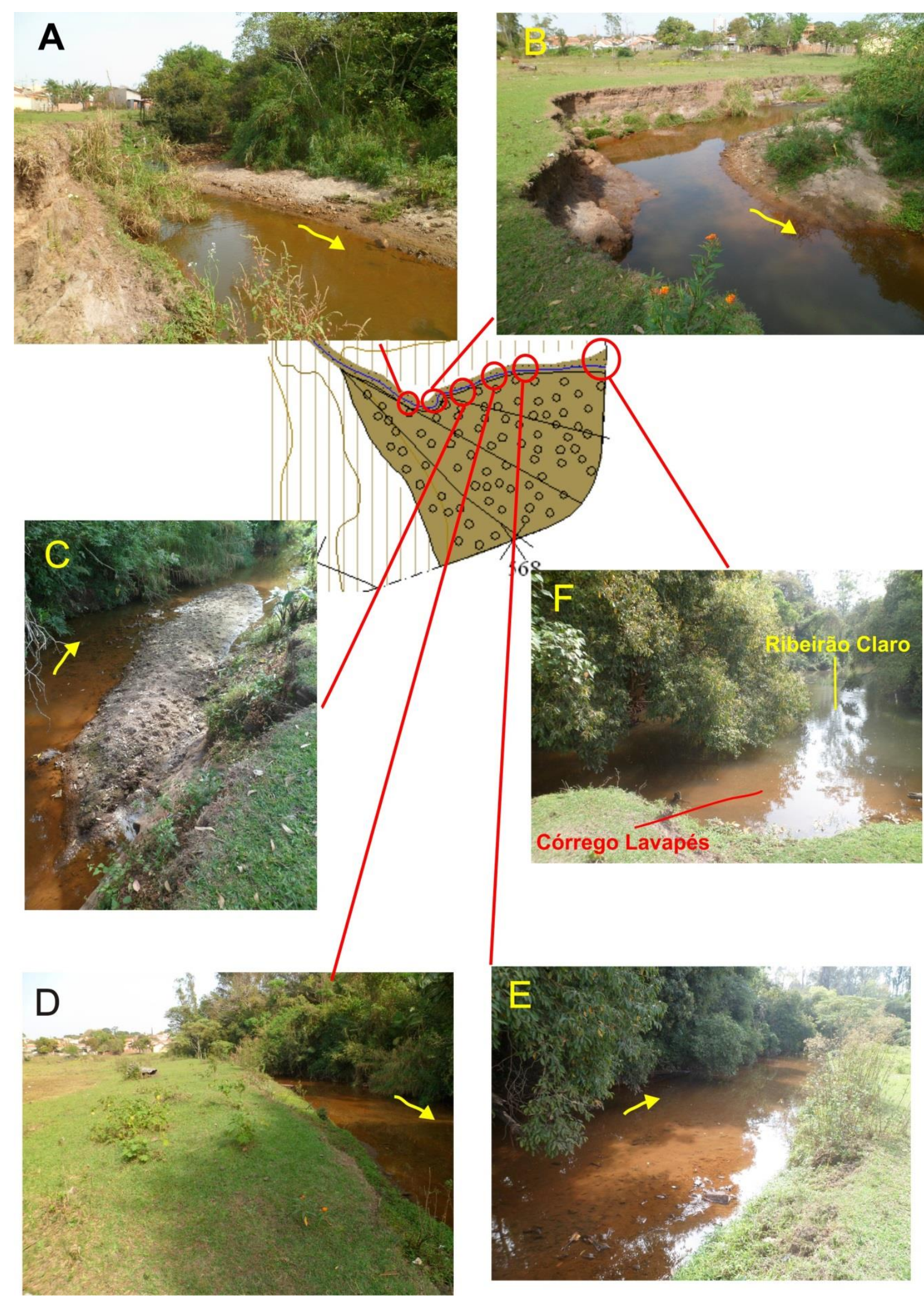

Figuras 17: (A) Sedimentos depositados e proximidade com a mata ciliar; (B) Dinâmica erosiva e deposicional; (C)

Ilha de sedimento nas proximidades da foz do córrego; (D) Diferença entre o leito do córrego e o leito aluvial; (E) Talvegue do córrego, antes do desague no Ribeirão Claro; (F) Encontro do Córrego Lavapés com o Ribeirão Claro. Fotos: Os autores. Org: Os autores. 


\section{CONSIDERAÇÕES FINAIS}

Através dos resultados expostos, pode-se considerar que a evolução do uso da terra na bacia hidrográfica do Córrego Lavapés causou modificações em sua dinâmica geomorfológica. Por essa área possuir um relevo com baixas declividades, seu uso foi destinado à urbanização, levando à modificação de várias formas e processos geomorfológicos.

As vertentes da alta e média bacia foram sendo gradativamente incorporadas à área urbana. Em 1962, o cenário era de expansão, com grande parte da área destinada para a urbanização. Em 2010, a área se encontrava totalmente urbanizada. Na baixa bacia, apenas metade da área foi ocupada pela urbanização. Na área restante, se localiza a FEENA, que se configura como uma Unidade de Conservação, fato este que possivelmente impediu a extinção de mais áreas de silvicultura para a expansão urbana.

O talvegue e o vale do córrego Lavapés também foram incorporados ao uso urbano. Em 1962, este se encontrava retificado no alto e médio curso. Em 1988, o talvegue encontrava-se canalizado e seu vale ocupado pela Avenida Ulisses Guimarães. Em 2010, as obras de canalização encontravam-se no médio curso. O baixo curso não foi diretamente atingido pelas intervenções, mas sua dinâmica fluvial responde atualmente às intervenções antrópicas de montante, refletidas pela baixa energia de suas águas, causando assoreamento de seu leito. Portanto, buscou-se demonstrar através deste trabalho a importância da aplicação da cartografia geomorfológica histórico-evolutiva. Essa técnica nos oferece subsídios para a compreensão dos efeitos antrópicos nos sistemas geomorfológicos. A análise integrada das informações geomorfológicas com as informações de uso da terra, somados ao conhecimento dos processos estruturais, climáticos e antrópicos de esculturação do relevo, fornecem subsídios para a compreensão das ações antrópicas no meio natural.

\section{AGRADECIMENTOS}

À Fundação de Amparo à Pesquisa do Estado de São Paulo (FAPESP) - Processo no 2011/19476-0, pelo financiamento da pesquisa.

\section{REFERÊNCIAS}

CERRI, M.S. Proposta metodológica para o estudo de microbacias hidrográficas urbanizadas: o exemplo do córrego Lavapés. 1999. 184f. Dissertação (Mestrado em Conservação e Manejo de Recursos) Instituto de Geociências e Ciências Exatas, Universidade Estadual Paulista, Rio Claro, 1999.

CERON, A.O.; DINIZ, J. A. F. O uso das fotografias aéreas na identificação das formas de utilização agrícola da terra. Revista Brasileira de Geografia, Rio de Janeiro, v.28, nº 2, p.161-173, abr-jun.1966. (Coleção Periódicos).

CHRISTOFOLETTI, A. Análise de sistemas em geografia: introdução. São Paulo: Hucitec, 1979. 106 p.

COTTAS, L. R. Estudos geológico-geotécnicos aplicados ao planejamento urbano de Rio Claro-SP. Tese (Doutorado em Geologia Geral e de Aplicação). Volume 1. 1983. Instituto de Geociências e Ciências Exatas, Universidade Estadual Paulista, Rio Claro, 1983.

DREW, D. Processos Interativos Homem Meio-Ambiente. Rio de Janeiro: Bertrand Brasil, 2005.

GOUDIE, A. The human impact on natural environment: past, present and future. Oxford: Blackwell Publishing, 2006. 357 p.

HARDT, R. A. Identificação e diagnóstico dos impactos ambientais ocorridos nos cursos d'água localizados na faixa oeste da Floresta Estadual "Edmundo Navarro de Andrade" (Rio Claro/SP). 2009. 85f. Trabalho de Conclusão de Curso (Bacharelado em Geografia) - Instituto de Geociências e Ciências Exatas, Universidade Estadual Paulista, Rio Claro, 2009.

INSTITUTO BRASILEIRO DE GEOGRAFIA E ESTATÍSTICA. Manuais técnicos em geociências: manual técnico de uso da terra. $2^{\mathrm{a}}$ ed. Rio de Janeiro: IBGE, 2006.

INSTITUTO DE PESQUISA TECNOLÓGICA DO ESTADO DE SÃO PAULO (IPT). Mapa geológico do estado de São Paulo. Vol. 1. São Paulo: IPT, 1981. 
JORGE, M. C. O. Geomorfologia urbana: conceitos, metodologias e teorias. In: GUERRA, A. J. T. Geomorfologia Urbana. Rio de Janeiro: Bertrand Brasil, 2011. p.117-145.

MARQUES, J. S. Ciência geomorfológica. In: GUERRA, A. J.; CUNHA, S. B. (orgs). Geomorfologia: uma atualização de bases e conceitos. $4^{\mathrm{a}}$ ed. Rio de Janeiro: Bertrand Brasil, 2001. p. 23-50.

MORUZZI, R. B.; CUNHA, C.M.L.; OLIVEIRA, J.N.; PINTO, S.A.F.; ROSSETTI, L.A.F.G. Avaliação do efeito combinado de reservatórios e de intervenção na calha fluvial para atenuação de cheias: o caso da bacia hidrográfica do Córrego da Servidão - Rio Claro/SP. In: CONGRESSO BRASILEIRO DE RECURSOS HÍDRICOS, 16., 2009. Anais..., 2009, p.1-13.

NIR, D. Man, a geomorphological agent: an introduction to anthropic geomorphology. Jerusalém: Keter Publishing House, 1983. 165 p.

PENTEADO - ORELLANA, M. M. Estudo geomorfológico do sitio urbano de Rio Claro-SP. Noticia geomorfológica, Campinas, ano 21, n. 42, p. 23-56, 1981.

RODRIGUES, C. On Anthropogeomorphology. In: REGIONAL CONFERENCE ON GEOMORPHOLOGY, 1999. Rio de Janeiro. Anais... Rio de Janeiro. v. 1, 1999. p. 100-110.

RODRIGUES, C. Morfologia original e morfologia antropogênica na definição de unidades espaciais de planejamento urbano: exemplo na metrópole paulista. Revista do Departamento de Geografia (USP), São Paulo, v. 17, p.101-111, 2005.

RODRIGUES, C. Avaliação do impacto humano da urbanização em sistemas hidro- geomorfológicos. Desenvolvimento e aplicação de metodologia na grande São Paulo. Revista do Departamento de Geografia (USP), São Paulo, v. 20, p. 111-125, 2010.

ROSSETTI, L.A.F.G. Geotecnologias aplicadas à caracterização e mapeamento das alterações da cobertura vegetal intra-urbana e da expansão urbana da cidade de Rio Claro (SP). 2007. 115 f. Dissertação

(Mestrado em Geografia) - Instituto de Geociências e Ciências Exatas, Universidade Estadual Paulista, Rio Claro, 2007.

SILVEIRA, A. Diagnóstico ambiental do setor noroeste do sítio urbano de Piracicaba (SP): uma abordagem geográfica. 2009. 178 f. Dissertação (Mestrado em Geografia) - Instituto de Geociências e Ciências Exatas, Universidade Estadual Paulista, Rio Claro, 2009.

TRICART, J. Principes et méthodes de la géomorfologie. Paris: Maisson, 1965.

VERSTAPPEN, H.T.; ZUIDAN, R.A. van. ITC System of geomorphological survey. In: ITC Textbook of Photo-Interpretation. Enschede: International Institute for Aerial Survey and Earth Sciences, 1975.

ZAINE, J. E. Geologia da formação Rio Claro na folha Rio Claro (SP). 1994. 98 f. Dissertação (Mestrado em Geociências e Meio Ambiente) - Instituto de Geociências e Ciências Exatas, Universidade Estadual Paulista, Rio Claro, 1994.

ZAINE, J.E. Mapeamento geológico-geotécnico por meio do método do detalhamento progressivo: ensaio de aplicação na área urbana do município de Rio Claro (SP). 2000. 149 f. Tese (Doutorado em Geociências e Meio Ambiente) - Instituto de Geociências e Ciências Exatas, Universidade Estadual Paulista, Rio Claro, 2000. 